\title{
Temperature Monitoring During Forging Process
}

\author{
Zdenek Chval, Karel Raz \& Milan Cechura
}
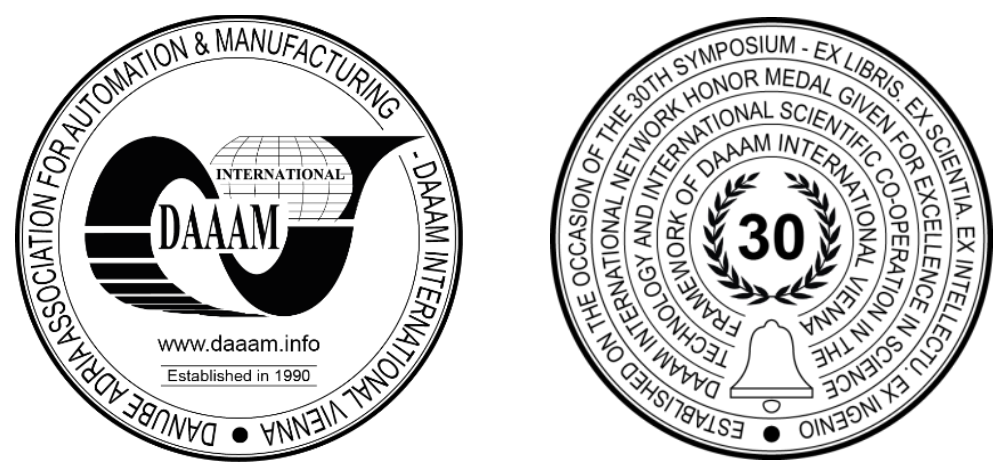

This Publication has to be referred as: Chval, Z[denek]; Raz, K[arel] \& Cechura, M[ilan] (2019). Temperature Monitoring During Forging Process, Proceedings of the 30th DAAAM International Symposium, pp.0359-0363, B. Katalinic (Ed.), Published by DAAAM International, ISBN 978-3-902734-22-8, ISSN 1726-9679, Vienna, Austria DOI: $10.2507 / 30$ th.daaam.proceedings.048

\begin{abstract}
This article deals with the measurement of the thermal behaviour of the mechanical forging press. The forging process is causing thermal changes. The temperature of the forged part can reach $1100-1200{ }^{\circ} \mathrm{C}$ during the hot forging. Heat transfer is causing thermal deformations of individual parts and it can change clearance in the guidance. It is decreasing the accuracy of press. Demands on the accuracy are nowadays more significant and therefore is necessary to solve problem with thermal deformations.
\end{abstract}

Keywords: forming machines; forging press; hot forging; temperature influence.

\section{Introduction}

Higher demands on accuracy of forged parts are resulting in new challenges and problems during the design process of a forging press. It is necessary to consider the influence of the temperature during designing of a new machine. This thermal influence (thermal deformations) has to be eliminated or used as a benefit for forging machine.

Increasing of the clearance can be considered as an example. It leads to correct moving conditions during higher thermal loading. These design modifications were performed mainly with respect to the operating experience. Size of the clearance in the guidance were higher in order to prevent any problems. This solution has problems during forging at lower temperature. Clearances are too big in that case and accuracy of forging press is lower. [4]

Forging machine are affected by following thermal influence:

1. The heat from the forged part (from the forging process)

2. The heat generated in the forging press (friction between moving parts, expansion of working fluid, friction clutch, brake, etc.)

3. The heat from the surrounding environment.

This article deals with the heat generated by the forged part. The temperature of the forged part can reach $1100-1200{ }^{\circ} \mathrm{C}$ during the hot forging process. The most critical area is the working space of the forging press. It has higher influence on the accuracy of final product. Therefore, this matter was given special attention and measurements were made on the machine during operation. [5], [6], [7] 


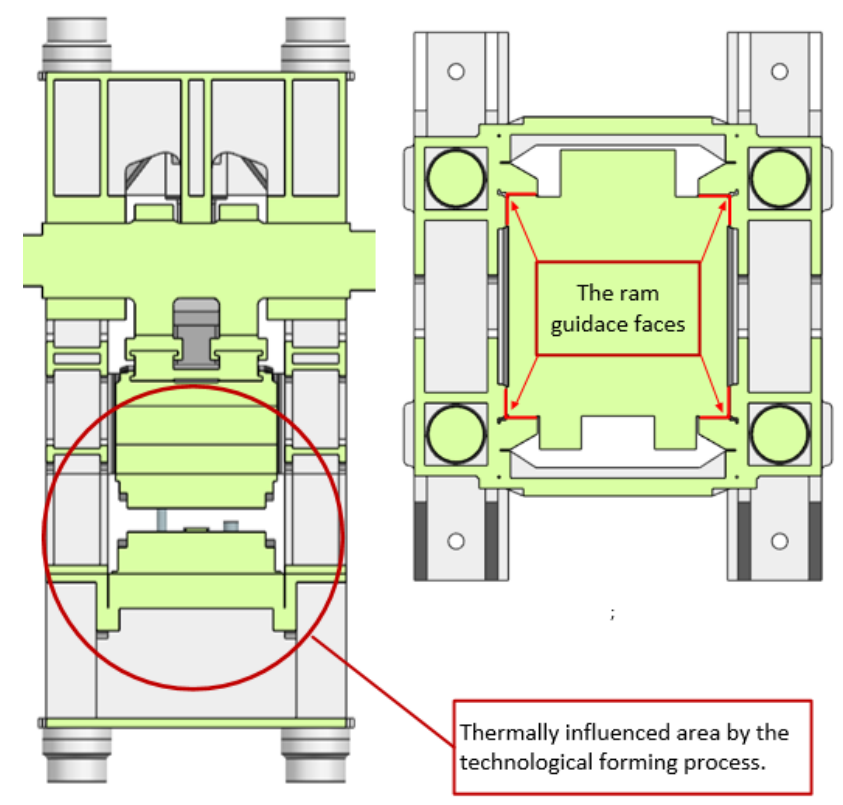

Fig. 1. The press with the description of the thermally influenced area

\section{The measurement of thermal loading during the hot forging process}

The thermal measurement was performed on the mechanical forging press with force $6500 \mathrm{t}$. The technological operation was hot forging of part with the diameter $130 \mathrm{~mm}$, length $310 \mathrm{~mm}$ and weight $29 \mathrm{~kg}$. The initial temperature of the part was $1150{ }^{\circ} \mathrm{C}$ and the heating was performed by the induction. The forging process had three steps [8]:

1. Upsetting

2. Preforming

3. Finish forging
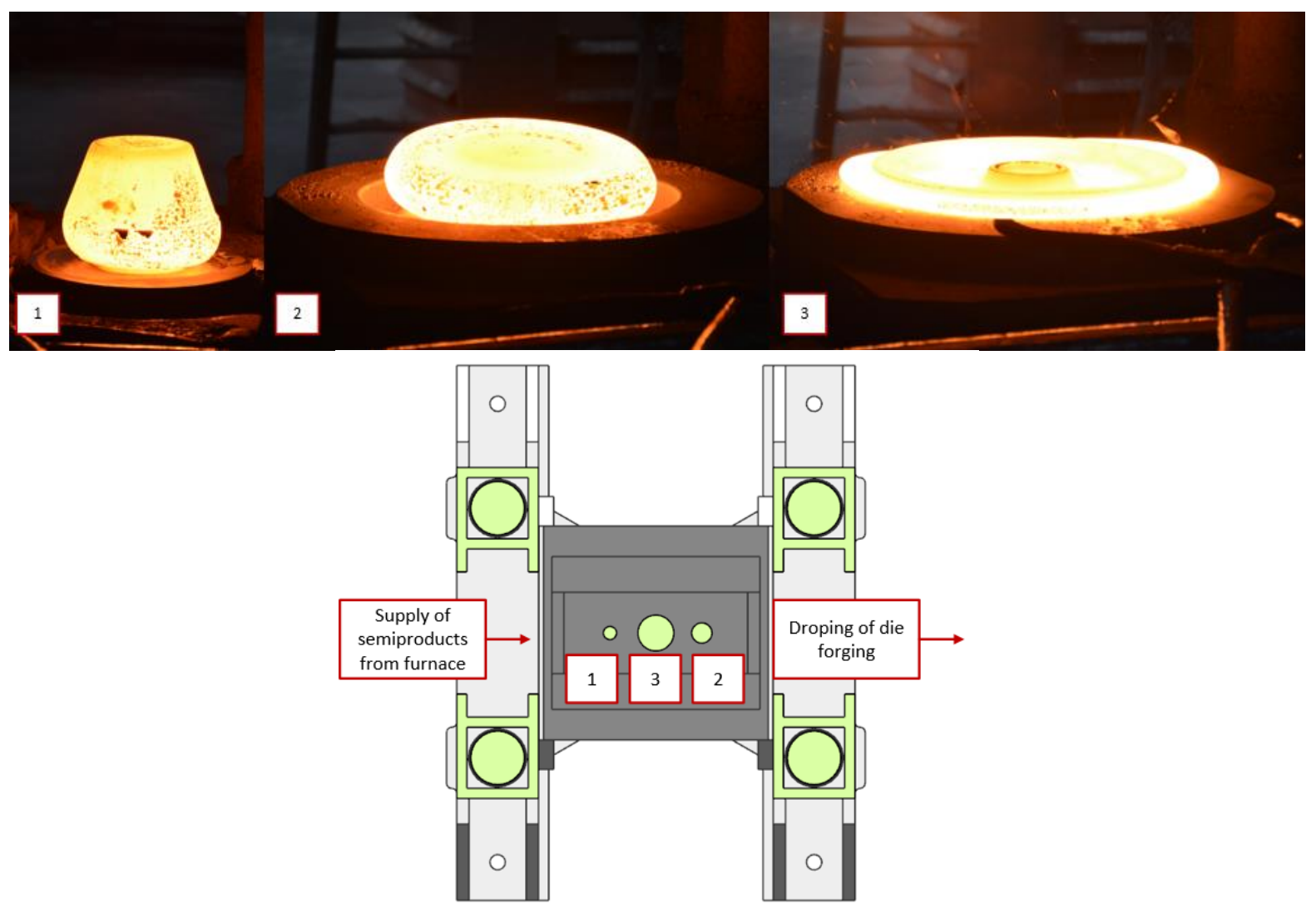

Fig. 2. Forging process- three technological operations 


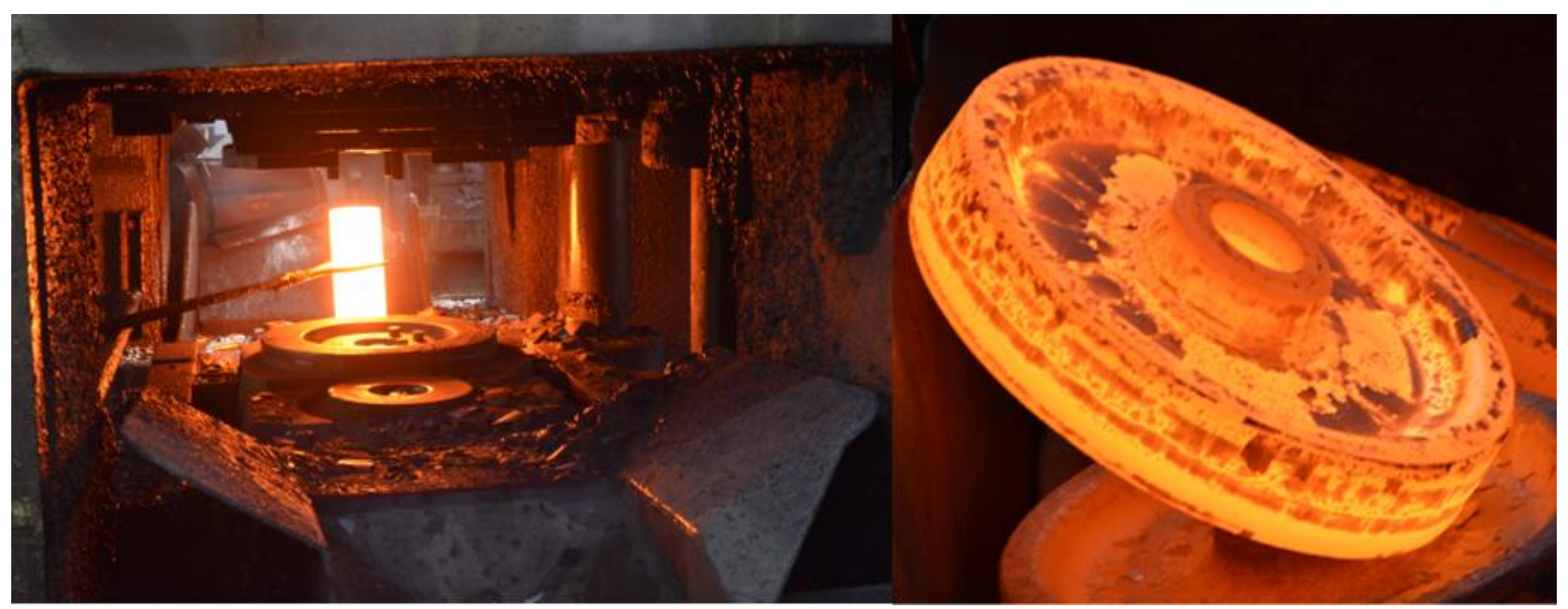

Fig. 3. View into the working space of the press through the side window

Parameters of the forging process and settings of the measurement:

1. The measurement started at the beginning of forging process, preheating of dies was performed by the gas burner.

2. The forged part was moved into the working space of the press through the left window and removed through the right window.

3. The forged part was in the working space of press around 20s. This time depends on the operator's ability to set the part into the correct position.

4. Time interval of parts transfer from the furnace was $100 \mathrm{~s}$.

5. The measurement of the temperature was performed at four reference points on the frame and the ram.

6. The temperature measurement was performed by usage of the infrared camera [1], [2], [3], [9].

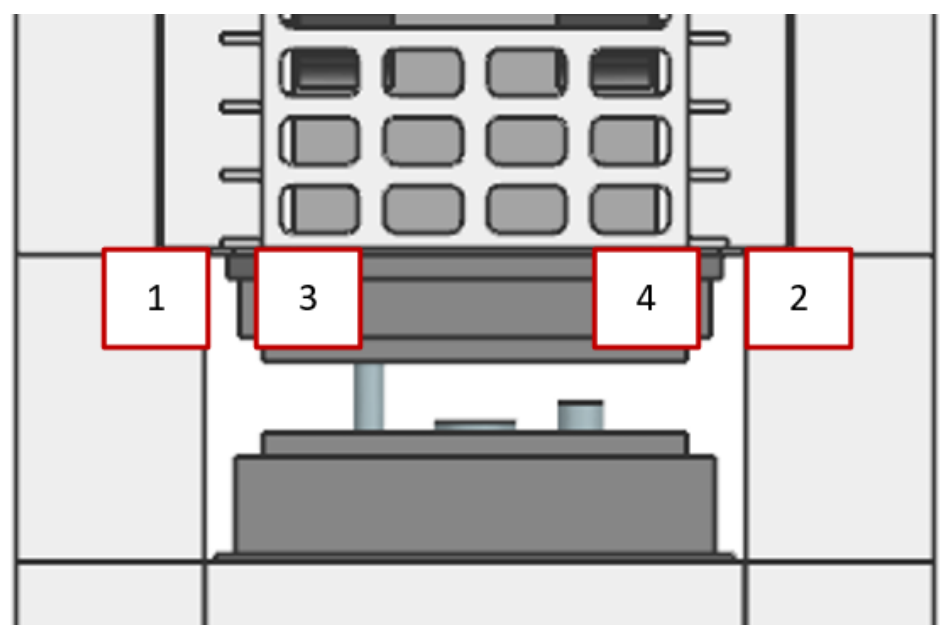

Fig. 4. Points measured by the infrared camera

\section{Results of the measurement}

The measurement shows, that most significant is influence of the preheating process. Points close to dies (points 3 and 4 ) have highest temperature. The temperature was decreasing during the measurement process. The highest temperature was right after the preheating process and it stopped at constant value after few hours. The preheating process does not affect reference points 1 and 2 and it took time to transfer heat from the forging process to these points. The temperature was therefore increased slightly.

The non-uniformity of the frame's heat loading is caused by the non-uniformity of the preheating process. The difference between the right and the left side of the frame (after preheating) is $17^{\circ} \mathrm{C}$ (for the die holder). This non-uniformity is removed after 5 hours of the forging process. It is confirming significant influence of the preheating process.

Second aspect supporting non-uniformity is insertion of the forged part to the working space through the left window. The temperature at this point is higher comparing to the right window. Shape of the forged part is more suitable for the heat transfer in the left window comparing to the right window (final shape of part). 


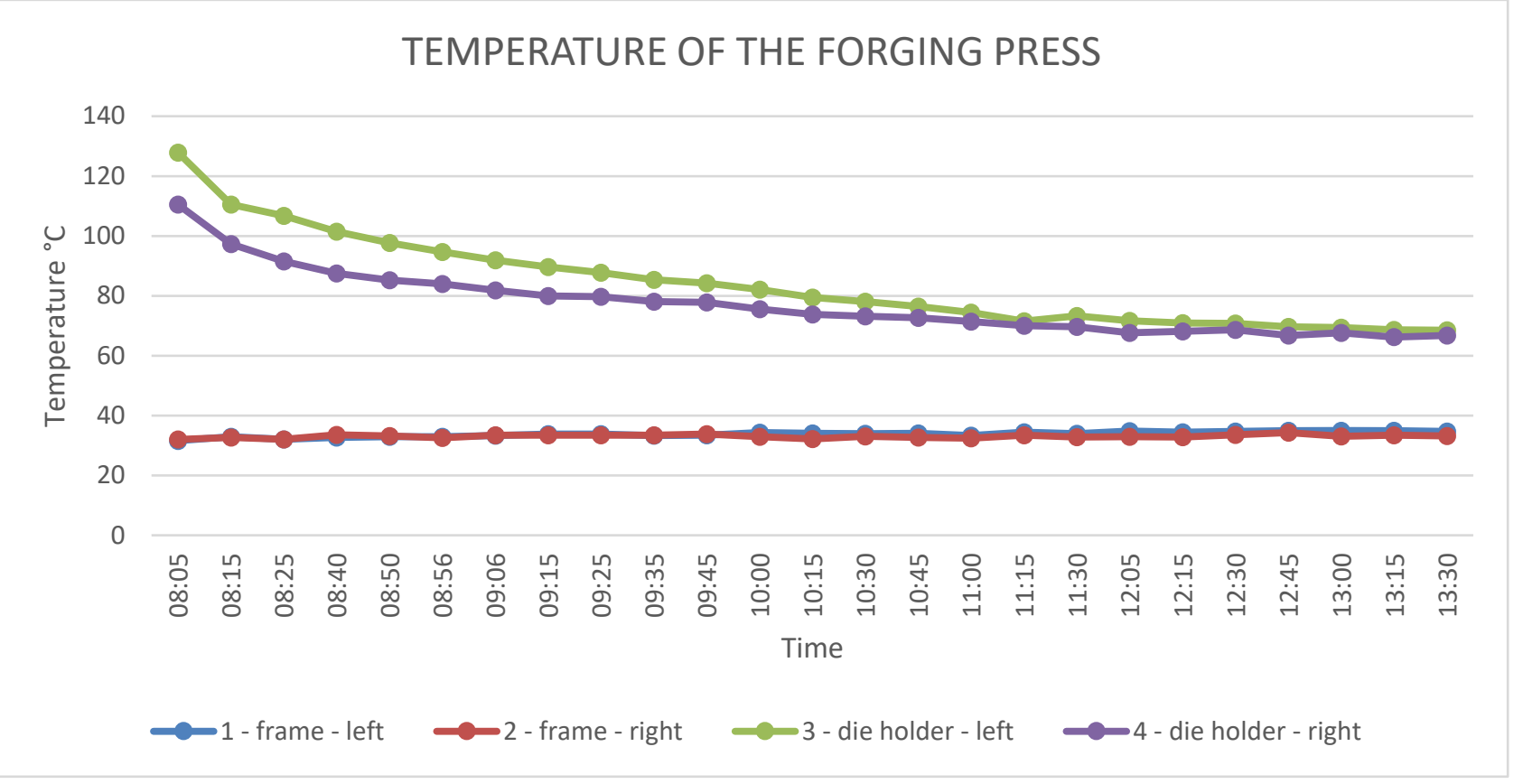

Fig. 5. Temperature of four reference points
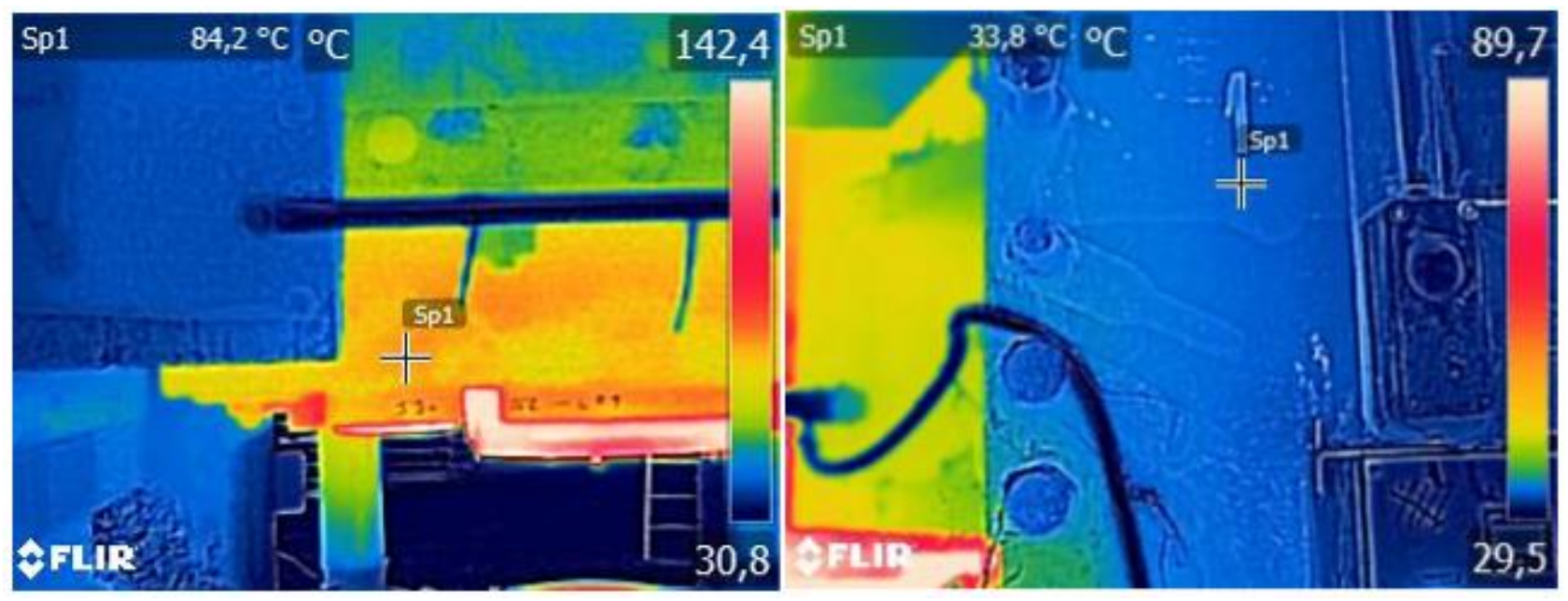

Fig. 6. Results from the infrared camera at points 3 and 2

\section{Conclusion}

The measurement of the temperature showed the main influence of the preheating process of dies. The main forging process doesn't have increasing influence on the temperature. The setting of the clearances sizes can be performed according the deformations after preheating process (before forging of individual parts). The press, the forging ram and dies (tools) are cooling down during the forging process is and it is resulting into the decreasing of the accuracy. Next step is to validate how the time interval of forging is influencing the thermal loading. This can lead to higher thermal influence. It is necessary to focus more on the preheating process and improve it in order to do not affect the accuracy of forging press.

\section{Acknowledgments}

This paper has been prepared under project LO1502 'Development of the Regional Technological Institute' under the auspices of the National Sustainability Programme I of the Ministry of Education of the Czech Republic aimed at supporting research, experimental development and innovation. 


\section{References}

[1] Chval, Z., Raz, K. (2016) Effect of heat load on a mechanical forging press. In Proceedings of the 27th DAAAM International Symposium. Vienna: DAAAM International, pp. 344-348. ISBN: 978-3-902734-08-2, ISSN: 17269679

[2] Marek, V. (2016). Basic Research of Thermal Transfer Simulations, Proceedings of the 27th DAAAM International Symposium, pp.0578-0585, B. Katalinic (Ed.), Published by DAAAM International, ISBN 978-3-902734-08-2, ISSN 1726-9679, Vienna, Austria, DOI: 10.2507/27th.daaam.proceedings.085

[3] Marek, V., Hajicek, Z. (2017). Thermal Simulations Based on Macro-Models, Proceedings of the 28th DAAAM International Symposium, pp.0627-0634, B. Katalinic (Ed.), Published by DAAAM International, ISBN 978-3902734-11-2, ISSN 1726-9679, Vienna, Austria, DOI: 10.2507/28th.daaam.proceedings.089

[4] Raz, K., Cechura, M., Chval, Z. (2015) Upper Crossbeam of Free Forging Press Optimization in Order to Improve Mechanical Properties and Durability. In Annals of DAAAM for 2015. Vienna: Danube Adria Association for Automation and Manufacturing, DAAAM, 2016. pp. 524-529. ISBN: 978-3-902734-07-5, ISSN: 1726-9679

[5] Zheng, E, Xie, S., Zhang, J., Zhu, Y., Zhao, X., Lin, X., Kang, M., (2018) An improved thermal model for characteristics analysis of multi-link ultra-precision press system, Journal of Mechanical Science and Technology, Volume 32, Issue 1, 1 January 2018, pp. 291-313

[6] Hawryluk, M., Kaszuba, M., Gronostajski, Z., Sadowski, P. (2016). Systems of supervision and analysis of industrial forging processes. Eksploatacja i Niezawodnosc 18(3), pp. 315-324

[7] Hawryluk, M. (2016). Review of selected methods of increasing the life of forging tools in hot die forging processes, Archives of Civil and Mechanical Engineering, 16(4), pp. 845-866

[8] Chval, Z., Raz, K, Kalina, T. (2018) Thermal analysis of the forging press LZK 4000, Annals of DAAAM and Proceedings of the International DAAAM Symposium Volume 29, Issue 1, 2018, Pages 740-745,

[9] Stehlik, A.; Vrtacek, J.; Pekovic, M. \& Jenicek, S. (2018): Measurement of Phase Transformation Temperatures Under Near-Real Conditions Using a Thermomechanical Simulator, Proceedings of the 29th International DAAAM Symposium "Intelligent Manufacturing \& Automation", 24-27th October 2018, Zadar, Croatia, Volume 29, No.1, ISSN 1726-9679, ISBN 978-3-902734-20-4 